\title{
Emerging Synergies in Innovation Systems: Creative Industries in Central Europe
}

\author{
Izabella Szakálné Kanó ${ }^{1}$ D $\cdot$ Zsófia Vas $^{1}$ (D) . Slávka Klasová ${ }^{2}$
}

Received: 27 February 2021 / Accepted: 17 December 2021

(c) The Author(s) 2022

\begin{abstract}
The window of opportunity has opened for the creative industries in Central Europe in the decades following the fall of the communist regime and the transition to a decentralised market economy. Creative industries with symbolic knowledge base are crucial for regional resilience, and regional synergies established by these economic activities highly influence the long-term ability of innovation systems to develop. The question is whether creative industries have started to grow and can contribute to the development of post-socialist knowledge-based economies in Central Europe, if so, at what territorial level. By distinguishing three dimensions (geography, technology, organisation) that operate in innovation systems and by measuring their interactions using entropy statistics in two post-socialist countries, Slovakia and Hungary, the paper reveals that the most significant part of the synergy in creative industries emerges at the local level of innovation systems. However, benefits are realised not only locally but also globally due to the deterritorialised nature of the end-products and their integration into other industrial products on the global market.
\end{abstract}

Keywords Innovation system $\cdot$ Synergy $\cdot$ Creative industry $\cdot$ Symbolic knowledge base $\cdot$ Central Europe $\cdot$ Entropy

\section{Introduction}

Creative industries have become a crucial component of policy agenda in modern post-industrial knowledge-based economies. Creative industries are in strategic position to promote economic growth in all EU regions (Foray et al., 2012;

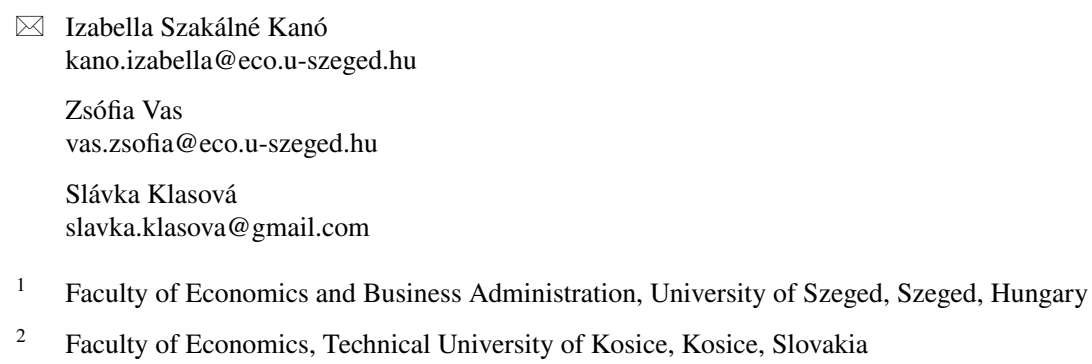


Boix-Domènech \& Rausell-Köster, 2018). They rely on creativity and intellectual capital, enhance entrepreneurial and innovation potential, and employ highly qualified and skilled labour that may drive local economies to prosperity and strengthen creative economy (Power \& Scott, 2004; UNCTAD, 2010; Lazzaretti 2013; Boix et al., 2016; Kemeny et al., 2020). In creative industries, innovation is highly complex, dynamic, and primarily based on tacit knowledge flows. Creative industries require face-to-face communication, local capacities, and buzz to innovate and to comprise both tangible products and intangible intellectual or artistic services (UNCTAD, 2008), even though the products are often deterritorialised and highly global (Plum \& Hassink, 2014). The knowledge base that influences their innovation potential and spatiality is dominantly symbolic (Asheim et al., 2007, 2011; Aslesen \& Freel, 2012).

The relevance of knowledge bases is shown by the fact that it predetermines the adaptability of an industry to overcome a crisis and take advantage of opportunities. Studies (e.g. Felton et al., 2010; Pratt, 2015) reveal that creative industries with symbolic knowledge base can contribute to regional resilience, and regional synergies established by the creative economic activities influence the long-term ability of regional economies for adaptation and development (Simmie, 2014; Martin \& Sunley, 2015). Creativity and innovation have great significance in the development of competitive advantage of regions (Malecki \& Hospers, 2007). Such competitive advantage is also highly dependent on institutional configuration in which regions are embedded (Swyngedouw, 2000).

In Central Europe, the fall of the communist regime in 1989 and the massive transformation from a centrally planned economy to a decentralised market economy brought many threats, but also opportunities (Kornai, 2006). The transition to the new economic system - even if it did not begin immediately resulted in, among others, higher GDP growth rates, higher labour productivity, and increased entrepreneurial activity. The transition was greatly accelerated by external factors, like geographical proximity to EU countries, adaptation of foreign examples, learning foreign experiences in educational institutions, developing trade relations, entry of foreign investors, and availability of modern technologies (Fidrmuc et al., 2002; Kornai, 2006). The time of centralised and planned economy was conducive to industrialisation, while the service sector was relatively under-developed, and creative economic activities were neglected. However, in Central Europe, as a result of political and economic liberalisation, everything has changed. Since the transition, and especially after the accession to the European Union (Bialic-Davendra et al., 2016), the window of opportunity has opened for the creative industries to grow in Central Europe rapidly.

The question is whether creative industries have started to grow and can contribute to the development of post-socialist knowledge-based economies in Central Europe, if so, at what territorial level. In other words, the paper aims at answering the research question of whether the configuration of innovation systems in Central Europe with creative industries can be detected, if so, by dividing it into local, regional, and national components, which geographical level is the most prevalent. The aim of the study is to confirm theory-led expectations about configuration of systems based on creative industries. We build on the concept of 
configuration of systems (Leydesdorff et al., 2006) and presume that economic benefits of creative industries characterised by symbolic knowledge base emerge at the level of the local innovation system. To prove it, we measure synergy for the Central European (Hungarian and Slovakian) national, regional, and local innovation systems as the reduction of uncertainty using mutual information among the three dimensions of geographical location, technological knowledge base, and organisational size. Dynamic correlation among technology, geography and organisation generates synergy in innovation systems.

\section{Creative Industries and Knowledge Base}

Knowledge-based economy relies on the crucial role of creative industries. They are the new engines of economic growth and major sources of innovation. In recent decades, the dynamic growth of creative industries has been further facilitated by the emergence of digital technologies. The phenomenon and spatiality of creativity came to the fore firstly due to Richard Florida's well-known works (Florida, 2002, 2005), and since that, it has been studied by many others (e.g. Power \& Scott, 2004). Florida has revealed the strategic role of creativity in localised innovation and regional competitiveness. Creativity increases the value of knowledge and, as a factor of local economic development, covers a great variety of professions and industries.

The interpretation of creative industries is extremely diverse and varies among countries. Different models exist for theory building and empirical testing (UNCTAD, 2010). The conceptualisation of these industries was initially linked to the notion of creative arts and cultural industries (Hartley, 2005). Nowadays, a more complex view has emerged. Creative industry is a subset of creative economy and covers cultural and copyright industries. According to the frequently cited model from UK Creative Industries Mapping Document, creative industries are "those activities which have their origin in individual creativity, skill, and talent and which have the potential for wealth and job creation through the generation and exploitation of intellectual property" (Flew, 2012, p. 9). These industries usually comprise 13 different subsectors, such as advertising, architecture, arts and antique markets, computer and video games, crafts, design, designer fashion, film and video, music, performing arts, publishing, software, and television and radio, but several authors classify even $R \& D$, toys, and cultural tourism as creative industries (UNCTAD, 2010; De-Miguel-Molina et al., 2012).

Creative industries are usually highly concentrated in local urban areas and have a significant role in urban dynamics (Cooke \& Lazzeretti, 2008; Boix et al., 2016). Creative industries have a decisive impact on employment growth (Kemeny et al., 2020), especially on youth employment (EY, 2014), increase entrepreneurial skills (Mikić et al., 2020), generate creative spillovers, form regional clusters (Chapain et al., 2010), have high innovation potential especially in urban areas (Stam et al., 2008), and contribute to technological development and long-term growth. Their positive direct and indirect impact on regional innovation systems is proven (Boix-Domènech \& Rausell-Köster, 2018). However, the impact of the industries on the local economy depends on the characteristics of the urban system and the industrial structure (Kemeny et al., 2020). 
Creative industries comprise both tangible products and intangible intellectual or artistic services (UNCTAD, 2008). The value of products and services in these industries derives primarily from their symbolic nature (Power \& Scott, 2004). Creative economic activities have high innovation potential and a high level of entrepreneurship (Lazzeretti, 2013), which is influenced by their dominantly symbolic knowledge base (Aslesen \& Freel, 2012).

Knowledge bases influence the development trajectories of industrial and regional innovation systems. Knowledge bases are different in terms of their specific learning and innovation challenges, which justify their different sensitivity to geographical distance and, accordingly, the importance of spatial proximity for localised learning. The concept of differentiated knowledge bases provides an explanation for the combined effect of the different kinds of knowledge, the type of the economic activities, and spatiality and identifies the analytical, synthetic, and symbolic knowledge bases (Asheim \& Gertler, 2005; Asheim \& Coenen, 2006; Asheim et al., 2007). An analytical (science-based) knowledge base is dominant in economic activities, where knowledge creation is mainly based on formal university-industry collaborations, former, codified scientific results and R\&D processes (Asheim \& Gertler, 2005). Examples include genetics, biotechnology, and information technology. In these sectors, geographical distance does not play an important role as knowledge is based on a commonly accepted language that can be more easily codified and transferred. Therefore, knowledge sourcing occurs on a broad geographical scale, often within globally configured networks (Martin, 2012).

A synthetic (engineering-based) knowledge base prevails in industries, like machinery or automotive industry where incremental innovation is crucial and done by the modification of existing products and processes. Synthetic knowledge based industries require know-how, context-specific, and practical skills for knowledge production and diffusion (Asheim et al., 2011). Those skills are often provided by technical schools or on-the-job trainings (Asheim \& Coenen, 2006). Local embeddedness of the economic actors is moderate. Actors may have some global partnerships. Symbolic (art-based) knowledge base is related to the creation of meaning, aesthetic qualities, symbols, and other cultural artefacts (Asheim et al., 2007, 2011). Symbolic knowledge is highly tacit and context-specific, and outputs are closely related to a deep understanding of the habits, norms and "everyday culture" of specific social groups. In case of symbolic knowledge-based industries, like film production, geographical proximity is absolutely decisive; thus, knowledge flows and networks are expected to be locally configured (Martin \& Moodysson, 2013).

Studies empirically investigate that innovation networks and the spatiality of the industries usually can be defined by one dominant knowledge base (Martin \& Moodysson, 2011, 2013; Liu et al. 2013). However, the dominant knowledge base may change over time (Plum \& Hassink, 2011). Furthermore, the industrial knowledge base itself is not enough to explain the differences in innovation and economic performance. Researches empirically prove that different regional innovation systems lead to different innovation performances. Interestingly, the difference between the same kinds of industries in two different regions is greater than between two different industries in the same region (Chaminade, 2011; Gülcan et al., 2011). 
Empirical findings related to creative industries characterised by symbolic knowledge base reveal that they are highly sensitive to geographical proximity and more dependent on local technological capabilities, collaboration, and knowledge flows than industries dominated by analytic or synthetic knowledge base (Aslesen \& Freel, 2012). Creative industries contribute to the synergy in regional innovation systems; however, the contribution level is questionable due to the intangibleness of the end-products (Plum \& Hassink, 2014). These industries are market-oriented; products are often deterritorialised and reach the global market as an element of an innovative end-product.

\section{System Configuration and Synergy in Innovation Systems}

Development of knowledge-based economy is primarily related to knowledge bases and the economic role of innovation. Innovation is the result of both individual and collective processes and is influenced by the evolving interdependence among the basic elements of innovation systems, such as organisations, interactions, institutions, and infrastructure (Lundvall, 1992; Nelson, 1993). System-based approach highlights the role of knowledge functions in economic growth and development and contributes to understanding how technological innovation affects newly created and existing innovation systems (Hekkert et al., 2007). However, the unpredictable nature of technological innovation results in uncertainty, which fundamentally affects the constantly renewing economy (Dosi et al., 2005).

Based on Storper's "Holy Trinity" of economic development, dynamic correlation among technology, geography, and organisation generates synergy, and synergy is crucial for the strength of innovation systems (Leydesdorff \& Fritsch, 2006). Configurational information is understood as a reduction of the uncertainty in the system. If more uncertainty is reduced in the innovation system, then more mutual information is generated; therefore, configurational synergy is created at the system level.

In general, configurational information is measured using the mathematical theory of communication (Shannon, 1948; McGill, 1954; Abramson, 1963; Theil, 1972). Leydesdorff (2003) was the first who proposed the concept of configurational information to indicate synergy in Triple Helix relations. Then Leydesdorff et al. (2006) pointed out how to calculate knowledge system configuration. According to them, configuration of system depends on the geographical distribution of partners and on the stock of relations among them. Network of relations can resonate into a configuration, which is productive, innovative, and flourishing. The geographical dimension is usually investigated with the help of the postal codes of firms. However, geographical distribution is not the only relevant dimension for a configuration (Leydesdorff \& Fritsch, 2006).

The second dimension for configuration is technology (Leydesdorff et al., 2006). Due to the different characters of innovation processes, geographical conditions have different effects on economic sectors with different technological capabilities and potential for novelty production. Technology dimension can be captured by the NACE statistical classification of economic activities in the European Community. 
Assuming that division of labour can yield efficiency gains, it is expected that regions with a profiled configuration could be more productive than other regions. The division of labour among firms of various sizes can be considered a third determining factor of the quality of innovation systems (Braczyk et al., 2004; Fritsch, 2004). Average firm size in terms of numbers of employees is used as a proxy for the industrial organisation dimension (Pugh et al., 1969; Blau \& Schoenherr, 1971).

Leydesdorff and his co-authors modelled the overall dynamics of innovation systems and aggregated networks along these three dimensions of geography, technology, and organisation. They measured mutual knowledge flowing between the dimensions employing an indicator based on entropy statistics (Fig. 1) (Leydesdorff et al., 2006; Lengyel \& Leydesdorff, 2011). This made it possible to capture the reduction of uncertainty in the innovation system and the increase of synergy between knowledge functions, such as knowledge exploration, knowledge exploitation, and organisational control.

The three different knowledge functions can be measured by interactions between each pair of dimensions of an innovation system (Lengyel \& Leydesdorff, 2011). Knowledge exploration is understood as interrelation between technological and geographical dimensions, knowledge exploitation is defined in technological and firm-size dimension-pair, and organisational control is analysed in geographical and firm-size dimensions. The reduction of uncertainty in innovation processes depends on whether there is a synergistic interaction between the knowledge functions of the innovation system. Moreover, the interaction among knowledge functions is stochastic, and technological innovations constantly reshape the relations between the three mechanisms. As a result of networked configuration, uncertainty of innovation processes is decreasing. Therefore, if the extent of uncertainty reduction is captured, synergy in innovation systems can be measured.

Fig. 1 Synergy of knowledge functions in an innovation system. Source: Lengyel and Leydesdorff (2011, p. 681)

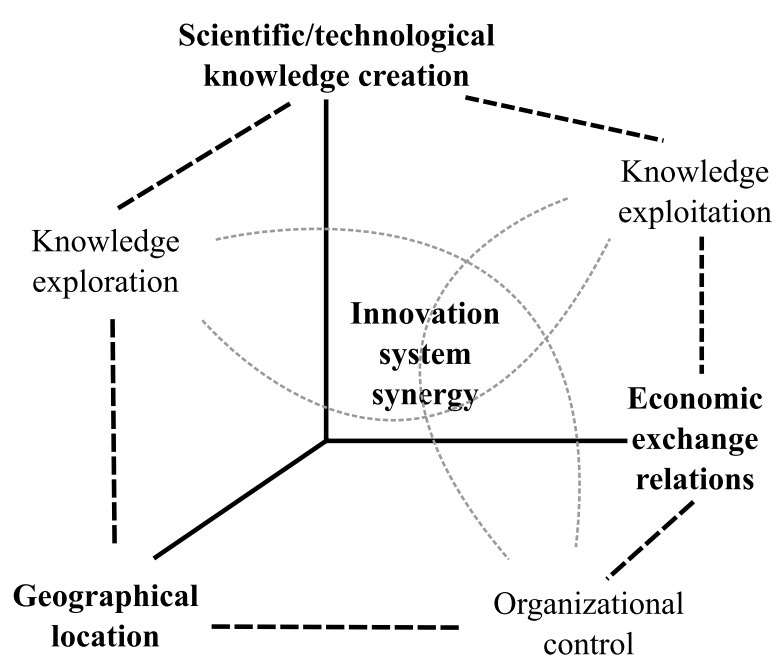




\section{Research Methodology}

To measure configuration of innovation systems in Central Europe based on creative industries with symbolic knowledge base, a unique database has become available. The firm-level database (legal entities using double-entry bookkeeping) in Slovakia from Statistical Register of Organization was provided by Statistical Office of Slovak Republic and in Hungary was provided by the Hungarian Central Statistical Office. All available data were gathered between the years 1998 and 2014.

In order to gain information on different territorial levels for both Central European countries in the same way (Table 1), we used the original NUTS3 and LAU1 division of the two countries with some modifications. In case of Hungary, Budapest is a NUTS 3 level unit; however, it is surrounded by county Pest; therefore, we handled these two units in our calculations as one. In case of Slovakia, the region Bratislava contains Bratislava city as a LAU1 unit, and similarly, the city of Kosice is a part of the region Kosice. In cases of these three cities (Bratislava, Kosice, and Budapest), we treated districts as LAU2 units.

The firm level data contains three variables, which are used as proxies for the three analysed dimensions: geography, technology, and organisation. The geographical distribution is indicated by the postal codes (in Slovakia) and settlements (in Hungary), both after data cleaning. We aggregated this classification into LAU1 and then into NUTS3 level units. Technology is specified by the classification related to economic activities and organisation by the company size in terms of numbers of employees (Pugh et al., 1969; Blau \& Schoenherr, 1971).

Due to the fact that there is no universal definition and measurement approach for creative economic activities, to run the analysis, we apply classification brought forward by Aslesen and Freel (2012), who assigned a set of NACE codes for industries (according to NACE Rev 1.) with symbolic knowledge base (Table 2). Because the Hungarian dataset was available according to NACE Rev 1., the Slovakian dataset according to NACE Rev 2., it was necessary to complete detailed correspondence between NACE Rev 1. and NACE Rev 2. related to symbolic knowledge-based creative industries.

For the quantification of configurational information (synergy indicator), dataset was organised into a structure that is shown in Table 3. For each firm, basic

Table 1 Number of territorial levels in Slovakia and Hungary

\begin{tabular}{|c|c|c|c|c|}
\hline \multirow[t]{2}{*}{ Territorial division } & \multicolumn{2}{|c|}{ Number of territorial units } & \multicolumn{2}{|c|}{$\begin{array}{l}\text { Territorial division of } \\
\text { capital cities (and Kosice) }\end{array}$} \\
\hline & Slovakia & Hungary & Slovakia & Hungary \\
\hline NUTS3 level (regions) & 9 & 19 & $5(4)$ & 23 \\
\hline LAU1 level (districts) & 79 & 175 & & \\
\hline LAU2 level (municipalities) & 1221 & 1603 & & \\
\hline
\end{tabular}

We calculated with those municipalities where we found firms in creative industries

Source: Authors' own elaboration 


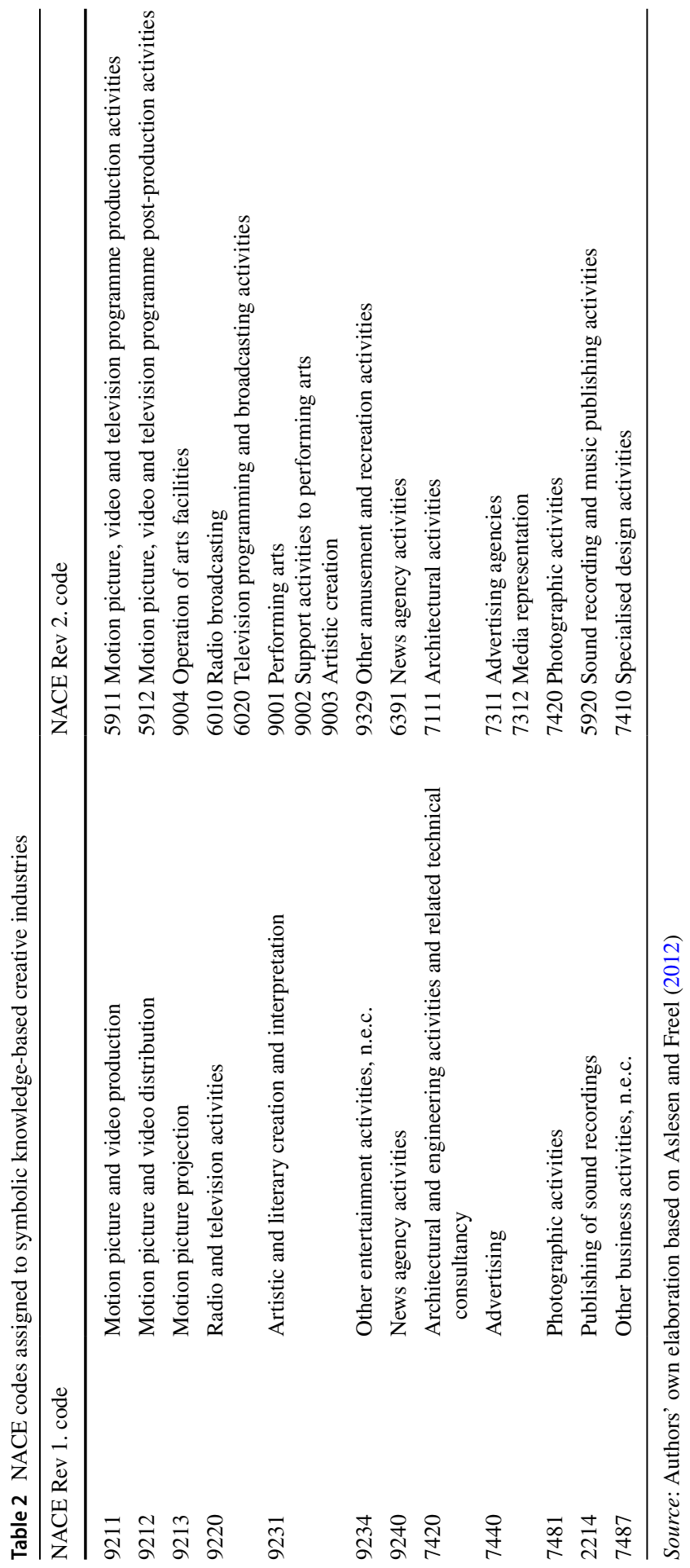


information is available for years between 1998 and 2014. The 17 years long time period was divided into four subperiods as follows: 1998-2002; 2002-2006; 2006-2010; and 2010-2014, each subperiod containing 5 years, because our goal was to gain a dynamic and robust picture about the synergy at the same time. (We examined shorter (yearly) periods in the case of Slovakia that showed the same pattern, what we have seen in the longer -5 years long - periods. In the case of Hungary, there was no possibility to conduct such a robustness check).

Configurational information (synergy) is calculated for both countries and each administration level (national, regional, and local) by using STATA according to the description provided through the website http://www.leydesdorff.net/softw are/th4/th4.prg.

Calculation of configurational information is closely related to entropy measures. Entropy is widely used in geography to map inequalities across or diversity within territorial units (Boschma \& Iammarino, 2009). Entropy is used as a measure of uncertainty represented in a probabilistic distribution or system of distributions (Johnston et al., 2000). According to Shannon's (1948) formula, uncertainty in the distribution of the variable $x$ (in our case $\mathrm{H}_{\mathrm{G}}, \mathrm{H}_{\mathrm{T}}, \mathrm{H}_{\mathrm{O}}$; where $\mathrm{G}=$ geography, $\mathrm{T}=$ technology, $\mathrm{O}=$ organisation) can be measured according to the equation:

$$
\mathrm{H}_{\mathrm{x}}=\sum_{\mathrm{i}=1}^{\mathrm{N}} \mathrm{p}_{\mathrm{i}} \log _{2}\left(\frac{1}{\mathrm{p}_{\mathrm{i}}}\right)
$$

where $\mathrm{p}_{\mathrm{i}}$ denotes the probability of $x$ taking the $\mathrm{i}$-th possible value $\mathrm{a}_{\mathrm{i}}$.

If the basis 2 is used for the logarithm, all values are expressed in bits of information. The sigma in the formula allows all the information terms to be fully decomposed. Analogously, $\mathrm{H}_{\mathrm{xy}}$ is the uncertainty in the two-dimensional probability distribution (matrix) of $x$ and $y$ (in our case $\mathrm{H}_{\mathrm{GT}}, \mathrm{H}_{\mathrm{TO}}, \mathrm{H}_{\mathrm{GO}}$ ) and can be measured according to Eq. (2):

Table 3 Data for calculating synergy indicator

\begin{tabular}{|c|c|c|c|c|c|}
\hline \multirow[t]{2}{*}{ Time period } & \multirow[t]{2}{*}{ Country } & \multicolumn{3}{|c|}{ Average number of sampled firms in territorial units } & \multirow{2}{*}{$\begin{array}{l}\text { Number of } \\
\text { sampled } \\
\text { firms }\end{array}$} \\
\hline & & $\begin{array}{l}\text { NUTS3 level } \\
\text { (regions) }\end{array}$ & $\begin{array}{l}\text { LAU1 level } \\
\text { (districts) }\end{array}$ & $\begin{array}{l}\text { LAU2 level } \\
\text { (municipalities) }\end{array}$ & \\
\hline 98-02 & Slovakia & 1099 & 122 & 7 & 8795 \\
\hline $02-06$ & & 1659 & 184 & 11 & 13268 \\
\hline $06-10$ & & 2378 & 264 & 16 & 19023 \\
\hline $10-14$ & & 2961 & 329 & 19 & 23686 \\
\hline 98-02 & Hungary & 618 & 67 & 7 & 11750 \\
\hline $02-06$ & & 1178 & 128 & 13 & 22383 \\
\hline $06-10$ & & 1545 & 168 & 17 & 29357 \\
\hline $10-14$ & & 1779 & 193 & 20 & 33801 \\
\hline
\end{tabular}

Source: Authors' own elaboration 


$$
\mathrm{H}_{\mathrm{xy}}=\sum_{\mathrm{i}=1}^{\mathrm{N}} \sum_{\mathrm{j}=1}^{\mathrm{M}} \mathrm{p}_{\mathrm{ij}} \log _{2}\left(\frac{1}{\mathrm{p}_{\mathrm{ij}}}\right)
$$

where where $\mathrm{p}_{\mathrm{ij}}$ denotes the probability of $x$ taking the $\mathrm{i}$-th value and $y$ taking the $\mathrm{j}$-th value possible.

In the case of two dimensions, the uncertainty in the two interacting dimensions $(x$ and $y)$ is reduced with the mutual information $\left(\mathrm{T}_{\mathrm{xy}}\right)$, which measures the "comovement" of these two dimensions. Using Shannon's formulas, this mutual information is defined as the difference between the sum of the uncertainty in two systems separately $\left(\mathrm{H}_{\mathrm{x}}+\mathrm{H}_{\mathrm{y}}\right)$ minus the uncertainty contained in the two systems when they are combined $\left(\mathrm{H}_{\mathrm{xy}}\right)$. This can be formalised as follows:

$$
\mathrm{H}_{\mathrm{xy}}=\mathrm{H}_{\mathrm{x}}+\mathrm{H}_{\mathrm{y}}-\mathrm{T}_{\mathrm{xy}} \Rightarrow \mathrm{T}_{\mathrm{xy}}=\mathrm{H}_{\mathrm{x}}+\mathrm{H}_{\mathrm{y}}-\mathrm{H}_{\mathrm{xy}}
$$

As stated above, these measures of mutual information can be treated as (1) knowledge exploration in case of interrelation between technological and geographical dimensions $\left(\mathrm{T}_{\mathrm{GT}}\right)$, (2) knowledge exploitation in case of technological and firm-size dimension-pair $\left(\mathrm{T}_{\mathrm{TO}}\right)$, and (3) organisational control for the geographical and firm-size dimensions $\left(\mathrm{T}_{\mathrm{GO}}\right.$ ) (Lengyel \& Leydesdorff, 2015).

Abramson (1963) derived from the Shannon's formulas that the mutual information in three dimensions is

$$
\mathrm{T}_{\mathrm{xyz}}=\mathrm{H}_{\mathrm{x}}+\mathrm{H}_{\mathrm{y}}+\mathrm{H}_{\mathrm{z}}-\mathrm{H}_{\mathrm{xy}}-\mathrm{H}_{\mathrm{xz}}-\mathrm{H}_{\mathrm{yz}}+\mathrm{H}_{\mathrm{xyz}}
$$

The value of $\mathrm{T}_{\mathrm{xyz}}$ in our case $\left(\mathrm{T}_{\mathrm{GTO}}\right)$ measures the interrelatedness of the three dimensions and the fit of the relations and correlations between and among them. $\mathrm{T}_{\mathrm{xyz}}$ has been used as an indicator of the potential reduction of uncertainty in complex systems in many disciplines (Ulanowicz, 1986; Jakulin \& Bratko, 2004). As was stated above, synergy reduces the uncertainty in the innovation systems.

This overall reduction of the uncertainty can be considered as a result of the networked configuration. Unlike the mutual information in two dimensions (Shannon, 1948; Theil, 1972), information among three dimensions can become negative (McGill, 1954; Abramson, 1963). Thus, a more negative value of $\mathrm{T}_{\mathrm{xyz}}$ $\left(\mathrm{T}_{\mathrm{GTO}}\right)$ will indicate a stronger uncertainty reduction and thus more synergy among the three dimensions of the innovation system.

One advantage of entropy statistics is that the values can be fully decomposed (Theil, 1972). In order to make a comparison of synergy generated at different territorial levels (districts, LAU1, or regions, NUTS3, or national level), we defined the value of average generated synergy in districts (Eq. 5) and regions (Eq. 6) of a country, respectively, as follows:

$$
\mathrm{T}_{\text {GTO LaU1 LaU2 }}=\sum_{\mathrm{i} \in \text { LAU1 districts }} \frac{\mathrm{n}_{\mathrm{i}}}{\mathrm{N}} \mathrm{T}_{\text {GTOi LaU1 }}
$$




$$
\mathrm{T}_{\text {GTO NUTS3 LAU2 }}=\sum_{\mathrm{j} \in \text { NUTS3 regions }} \frac{\mathrm{m}_{\mathrm{j}}}{\mathrm{N}} \mathrm{T}_{\text {GTOj LAU2 }}
$$

where

$\mathrm{n}_{\mathrm{i}}$ and $\mathrm{m}_{\mathrm{j}}$ are the number of firms in LAU1 district $\mathrm{i}$ and NUTS3 region $\mathrm{j}$, respectively $\left(\mathrm{N}=\sum_{\mathrm{i}} \mathrm{n}_{\mathrm{i}}=\sum_{\mathrm{j}} \mathrm{m}_{\mathrm{j}}\right), \mathrm{N}$ is the number of firms in the whole country, and $\mathrm{T}_{\mathrm{GTOi} \mathrm{LAU} 2}$ and $\mathrm{T}_{\mathrm{GTOj} \text { LAU2 }}$ are synergies measured in LAU1 district $\mathrm{i}$ and NUTS3 region $\mathrm{j}$, respectively.

The decomposition algorithm enables us to study Slovakia and Hungary as a composed system in terms of their lower-level units like the LAU1 districts and the NUTS3 regions:

$$
\begin{gathered}
\mathrm{T}_{\mathrm{GTO} \mathrm{LAU} 2}=\mathrm{T}_{\mathrm{GTO} \text { LAU1 }}+\mathrm{T}_{\mathrm{GTO} \text { LAU1 LAU2 }} \\
\mathrm{T}_{\mathrm{GTO} \mathrm{LAU} 2}=\mathrm{T}_{\text {GTO NUTS3 }}+\mathrm{T}_{\mathrm{GTO} \text { NUTS3 LAU2 }}
\end{gathered}
$$

where $\mathrm{T}_{\text {GTO LAU1 }}$ and $\mathrm{T}_{\text {GTO NUTS3 }}$ are the measures of between district and between region synergies, respectively, and $\mathrm{T}_{\text {GTOLAU1LAU2 }}$ and $\mathrm{T}_{\text {GTONUTS3LAU2 }}$ are the measures of the above defined (Eqs. 5 and 6) average generated synergies in districts and regions.

The between-group uncertainty-reduction $\mathrm{T}_{\mathrm{GTO} \text { LAU1 }}$ and $\mathrm{T}_{\mathrm{GTO} \text { NUTS3 }}$ are then defined as the difference between the uncertainty of the contributions and the uncertainty prevailing at the level of the composed set (Leydesdorff et al., 2006). In this case, $\mathrm{T}_{\text {GTO LAU1 }}$ (and $\mathrm{T}_{\text {GTO NUTS3 }}$ ) is an indicator of the between-group contribution to configurational information in three dimensions.

In case of between-districts interaction $\mathrm{T}_{\text {GTO LAU1}}$, one can further break it down by taking country level interaction on NUTS3 base and average intra-NUTS3 regional interaction on LAU1 base just in the similar manner we did it in Eqs. (5) and (6).

$$
\begin{gathered}
\mathrm{T}_{\mathrm{GTO} \text { LAU1 }}=\mathrm{T}_{\text {GTO NUTS3 }}+\mathrm{T}_{\mathrm{GTO} \text { NUTS3 LAU1 }} \\
\mathrm{T}_{\mathrm{GTO} \mathrm{LAU} 1}=\mathrm{T}_{\mathrm{GTO} \text { NUTS } 3}+\sum_{\mathrm{j} \in \text { NUTS3 regions }} \frac{\mathrm{m}_{\mathrm{j}}}{\mathrm{N}} \mathrm{T}_{\text {GTOj LAU1 }}
\end{gathered}
$$

where all these variables are defined under Eqs. (5) and (6), and $\mathrm{T}_{\mathrm{GTOj} \text { LAU1 }}$ is synergy measured in NUTS3 region $\mathrm{j}$ which is divided now instead of municipalities into districts.

With this substitution, we get Eq. (11).

$$
\mathrm{T}_{\mathrm{GTO} \mathrm{LAU} 2}=\mathrm{T}_{\mathrm{GTO} \text { NUTS3 }}+\mathrm{T}_{\mathrm{GTO} \text { NUTS3 LAU1 }}+\mathrm{T}_{\mathrm{GTO} \text { LAU1 LAU2 }}
$$

These three components represent now three levels of created synergy: the national $\left(\mathrm{T}_{\mathrm{GTO} N U T S 3}\right)$, the regional $\left(\mathrm{T}_{\mathrm{GTO} \text { NUTS3 LAU1 }}\right)$, and the local components $\left(\mathrm{T}_{\mathrm{GTO} \text { LAU1 LAU2 }}\right)$. A negative value of any $\mathrm{T}_{\mathrm{GTO}}$ indicator in decomposition Eq. (11) would point towards that the given level of agglomeration adds to the synergy in the 
system. At the same time, a positive value indicates that the synergy occurs (if it occurs) rather at another territorial level than at the given level.

In the same manner, we can divide knowledge exploration $\left(\mathrm{T}_{\mathrm{GT}}\right)$ and organisational control $\left(\mathrm{T}_{\mathrm{GO}}\right)$ into three components, because these two interaction measures also have the same - the geographical — dimension in common, just like the synergy measure $\left(\mathrm{T}_{\mathrm{GTO}}\right)$.

$$
\begin{aligned}
& \mathrm{T}_{\mathrm{GT} \mathrm{LAU} 2}=\mathrm{T}_{\mathrm{GT} \mathrm{NUTS} 3}+\mathrm{T}_{\mathrm{GT} \text { NUTS3 LAU1 }}+\mathrm{T}_{\mathrm{GT} \mathrm{LAU} 1 \mathrm{LAU} 2} \\
& \mathrm{~T}_{\mathrm{GO} \mathrm{LAU} 2}=\mathrm{T}_{\mathrm{GO} \mathrm{NUTS} 3}+\mathrm{T}_{\mathrm{GO} \mathrm{NUTS} 3 \text { LAU1 }}+\mathrm{T}_{\mathrm{GO} \mathrm{LAU} 1 \mathrm{LAU} 2}
\end{aligned}
$$

\section{Results}

For confirmation of our theory-led expectations, we calculated configurational information (synergy indicator) $\mathrm{T}_{\mathrm{GTO}}$ based on the methods described above for each district (LAU1) and regions (NUTS3) in Slovakia and Hungary, respectively, as a whole. After calculation of configurational information, we decomposed the decrease of uncertainty $\mathrm{T}_{\text {GTO LAU2 }}$ to find out whether national, regional, or local agglomeration adds to the synergy in the system. Comparison of different levels serves for defining their importance for further research related to knowledge bases, but especially for accurately targeted regional policy. Table 4 provides the results of synergy indicator at each administrative level for creative industries based on symbolic knowledge base. Values of the two countries cannot be compared directly because of the different number of territorial units (see Table 1). However, we can compare trends and the composition of the interaction on LAU2 base (see Eq. 11).

The most striking dissimilarity between the two countries' results is that synergy was continuously decreasing for Slovakia, but this pattern prevailed for Hungary only until 2010; after that, synergy increased to the value of period 2002-2006 (Fig. 2A, C). It is also important to mention that both countries had a positive trend in number of firms in industries with symbolic knowledge base (see Table 3 and Fig. 7).

In case of Slovakia, the decomposition of interaction $\mathrm{T}_{\mathrm{GTO} \text { LAU2 }}$ (Fig. 2B) shows that in the first two time periods, almost half of the reduction of uncertainty $(47 \%$ and $45 \%$, respectively) was generated between districts inside the NUTS 3 regions ( $\mathrm{T}_{\mathrm{GTO}}$ NUTS3 LAU1 $)$, and another 36-39\% came from the level inside the districts between municipalities ( $\mathrm{T}_{\mathrm{GTO} \text { LAU1 LAU2 }}$ ). These proportions changed to the last two periods, the biggest part of uncertainty was generated at local level $\left(\mathrm{T}_{\mathrm{GTO} \text { LAU1 LAU2 }} \propto 46 \%\right.$ and $49 \%$ ) and next was the regional level ( $\mathrm{T}_{\text {GTO NUTS3 LAU1 }} \propto 41 \%$ and $39 \%$ ).

In case of Hungary, this decomposition shows (Fig. 2D) a slightly different picture. The local level (inside the districts between municipalities: $\mathrm{T}_{\text {GTO LAU1 LAU2) }}$ delivered for all the periods the biggest part of the interaction $\mathrm{T}_{\mathrm{GTO} \text { LAU2 }}$, and this level accounted for $41-55 \%$ of it. The regional level (between districts inside the NUTS3 regions ( $\mathrm{T}_{\text {GTO NUTS3 LAU1 }}$ ) was responsible for $39-34 \%$ of the total interaction. 


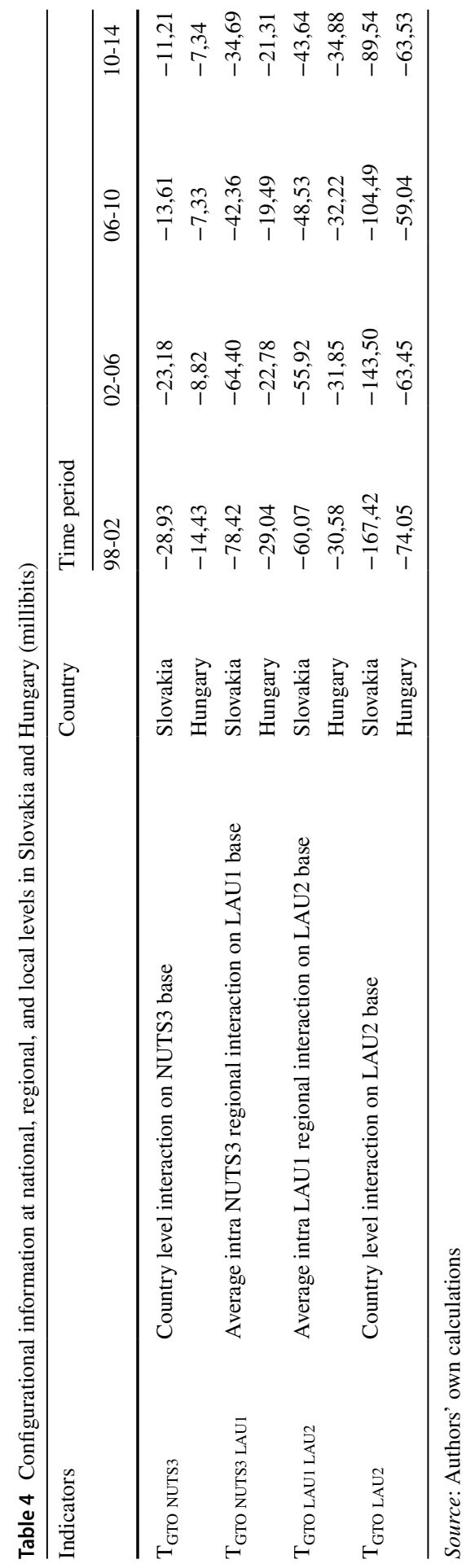



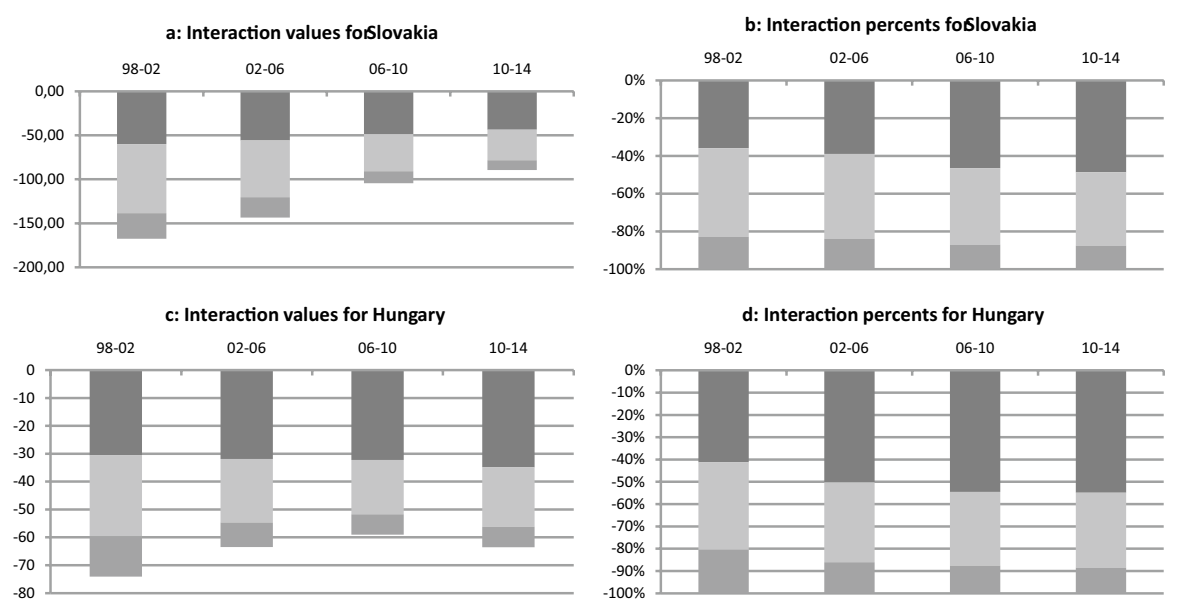

- Country level interaction on LAU2 base

Average intra NUTS3 regional interaction on LAU1 base

average intra LAU1 regional interaction on LAU2 base

Fig. 2 Composition of country level interaction on LAU2 base. Note: a and c, values are given in millibits; $\mathbf{b}$ and $\mathbf{d}$, values are given in \%. Source: Authors' own elaboration

The biggest providers of interaction were Budapest as a district and region Pest and its districts. The biggest providers of interaction were the district and region of Bratislava and regions Trnava and Banska Bystrica.

In both countries, results show that an important part of the uncertainty reduction is provided at a level lower than the NUTS-3 regions. In other words, higher synergy is generated at local (LAU1) level, which means that the network of relations at local level can resonate into a configuration, which is productive, innovative, and flourishing

In order to gain a more detailed picture of interaction generated between firms in creative industries with symbolic knowledge base in the two countries, we analysed the composition of the interaction values $\mathrm{T}_{\mathrm{GT}}, \mathrm{T}_{\mathrm{GO}}$ and $\mathrm{T}_{\mathrm{TO}}$. We can observe almost the same trend in all three interaction values and both countries (Figs. 3 and 4). Knowledge exploration $\left(\mathrm{T}_{\mathrm{GT}}\right)$ and organisational control $\left(\mathrm{T}_{\mathrm{GO}}\right)$ measures are decomposable into local, regional, and national parts; knowledge exploitation $\left(\mathrm{T}_{\mathrm{TO}}\right)$ is not because it does not contain the geographical dimension. The tendencies of all of the three interaction values show a decline in time, except in the last time period in case of Hungary, where there is a slight increase of all of the three interaction values. The largest value is always the local part, followed by the regional and national parts. These findings align with our theory-led expectations. In Hungary, we can observe an increasing share of local $\mathrm{T}_{\mathrm{GT}}$ from 60 to $65 \%$ and also an increasing share of local $\mathrm{T}_{\mathrm{GO}}$ from 87 to $90 \%$ of the total. In Slovakia, the share of local $\mathrm{T}_{\mathrm{GT}}$ stagnated around $68 \%$, and the share of local $\mathrm{T}_{\mathrm{GO}}$ increased from 90 to $94 \%$ of the total.

In case of knowledge exploration $\left(\mathrm{T}_{\mathrm{GT}}\right)$, we find the highest value in Budapest and Pest county in Hungary, which is similar to the Slovak case where the highest value we see in the Bratislava region, in both countries, the county of the capital city 
Slovakia

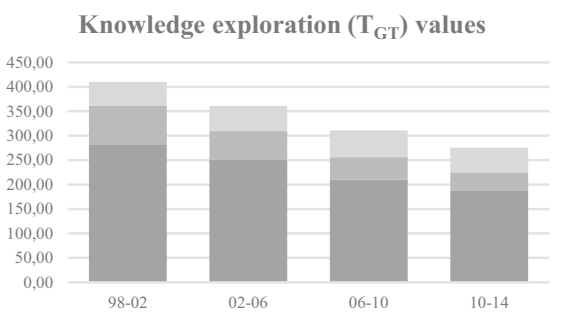

Organizational control $\left(\mathrm{T}_{\mathrm{GO}}\right)$ values

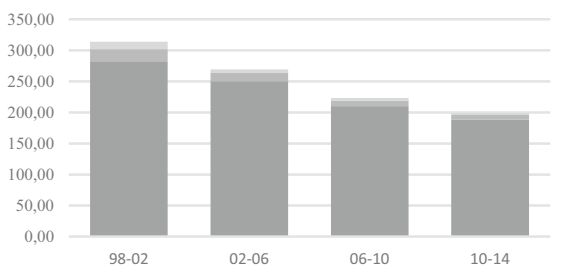

Country level interaction on NUTS3 base

- Average intra NUTS3 regional interaction on LAU1 base

- Average intra LAU1 regional interaction on LAU2 base
Hungary

Knowledge exploration $\left(\mathrm{T}_{\mathrm{GT}}\right)$ values

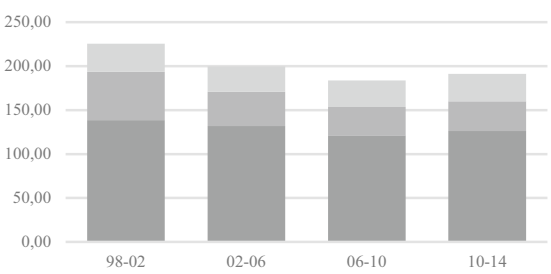

Organizational control $\left(\mathrm{T}_{\mathrm{GO}}\right)$ values

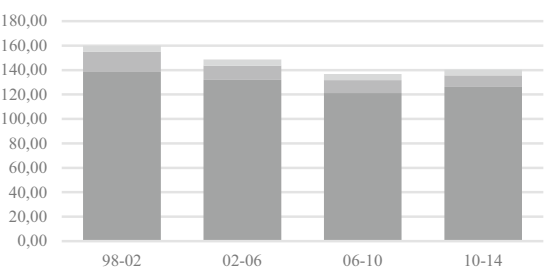

Fig. 3 Composition of country-level knowledge exploration $\left(\mathrm{T}_{\mathrm{GT}}\right)$ and organization control $\left(\mathrm{T}_{\mathrm{GO}}\right)$ measures on LAU2 base (millibits). Source: Authors' own elaboration

(Figs. 5a and 6a). In Hungary, the picture is similar in both other cases $\mathrm{T}_{\mathrm{GO}}$ and $\mathrm{T}_{\mathrm{TO}}$ : county of the capital city has the highest values (Fig. 4b, c). In the Slovak case, we find a different picture, $\mathrm{T}_{\mathrm{GO}}$ and $\mathrm{T}_{\mathrm{TO}}$ values are the lowest in the country (Fig. 5b, c)

The number of firms in creative industries with symbolic knowledge base grew during the period of interest at least to 3.7-fold of the original number in every county of Hungary. However, it partly happened due to a change in the regulations on mandatory double-entry bookkeeping in 2004, when in 1 year, the growth in the number of the firms of interest was $53.6 \%$ (Fig. 7). Without this outlier, Hungary

Slovakia

Knowledge exploration $\left(\mathrm{T}_{\mathrm{TO}}\right)$ values

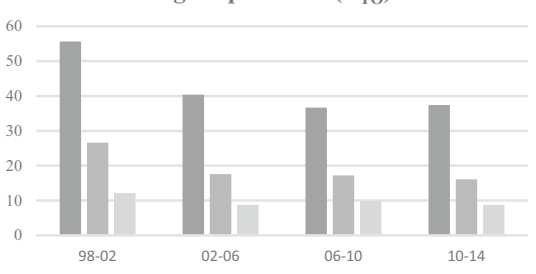

Hungary

Knowledge exploration $\left(\mathrm{T}_{\mathrm{TO}}\right)$ values

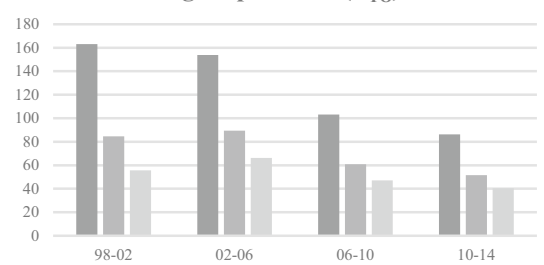

Fig. 4 Knowledge exploitation $\left(\mathrm{T}_{\mathrm{TO}}\right.$ ) values at local, regional and national levels (millibits). Note: Knowledge exploitation does not contain the geographic dimension, so it is not decomposable into local, regional and national parts. Source: Authors' own elaboration 

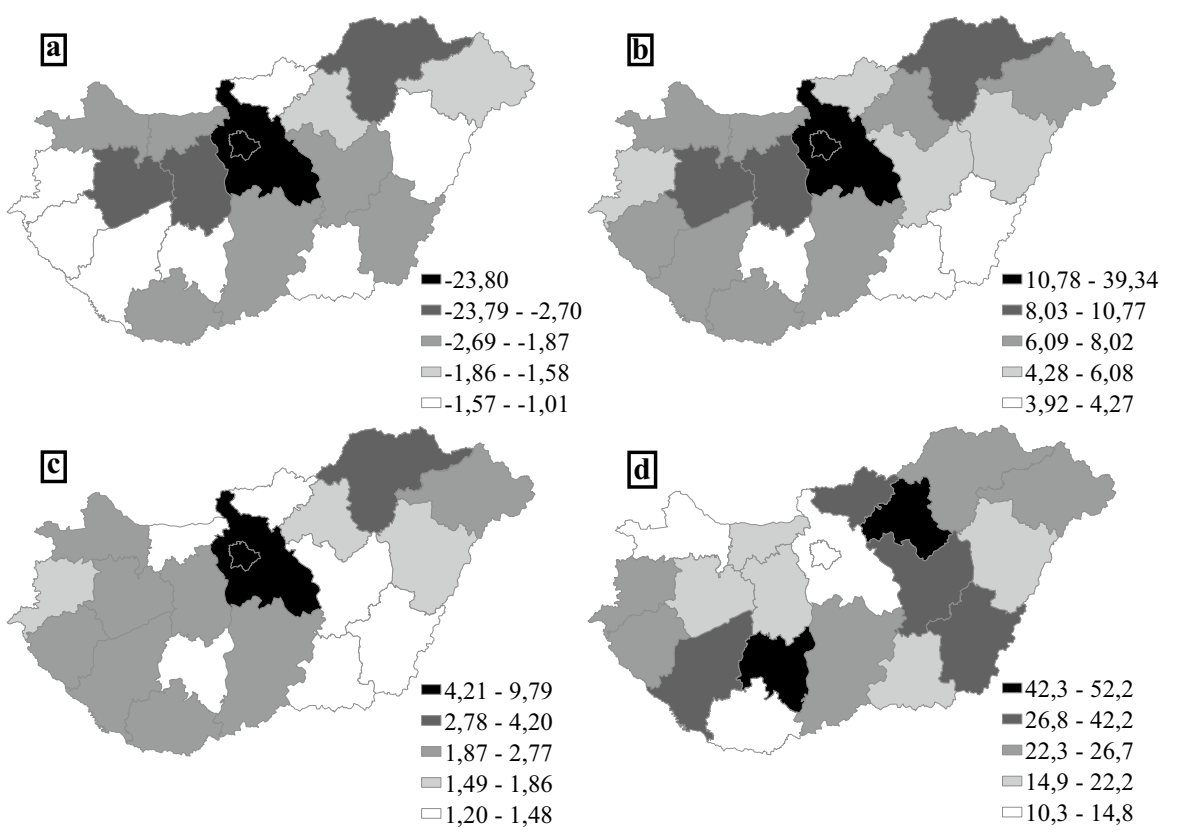

Fig. 5 Contribution of Hungarian counties to a national innovation system synergy, b national knowledge exploration, and $\mathbf{c}$ organisational control. d Hungarian counties' level of knowledge exploitation (all in millibits). Source: Authors' own elaboration

faced $6.47 \%$ growth in the number of these firms on annual average. While this growth was one of the smallest in county of Pest, it was the largest in one of the regions close to the Eastern border. In Slovak regions, the number of companies in creative industries with symbolic knowledge base has grown at least to 2.84 -fold of the original number in every county from 1998 to 2014. This means at least $6.74 \%$ growth on annual average in every Slovak county. While this rise was the smallest in two Northern regions, the largest in one region at the Western and one close to the Eastern border. This growth was more equalised in Slovak regions than in Hungarian ones.

Overall, the research pointed out two important facts. Firstly, in line with the theoretical expectation, it has become clear that economic benefits of creative industries with symbolic knowledge base are emerging at the local level of innovation systems. Local level is the most decisive for interaction, and the network of relations at local level can resonate into a configuration. It has been proved that in Central Europe, a major part of the reduction of the uncertainty is provided at a lower level than NUTS-3 regions, so higher synergy is generated at the local (LAU1) level. Not surprisingly, the biggest interaction providers were the capital cities and regions in Slovakia and Hungary and developed city regions in Slovakia. This crucial role of locality can be explained by the nature of the symbolic knowledge base. Due to the knowledge base, innovation is highly context-specific, and the meaning and value associated with the products can be different between social groupings and places. 
回

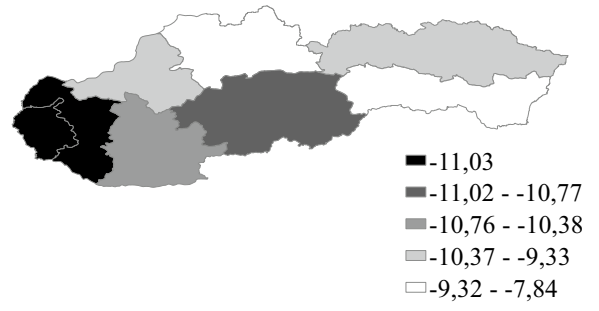

c

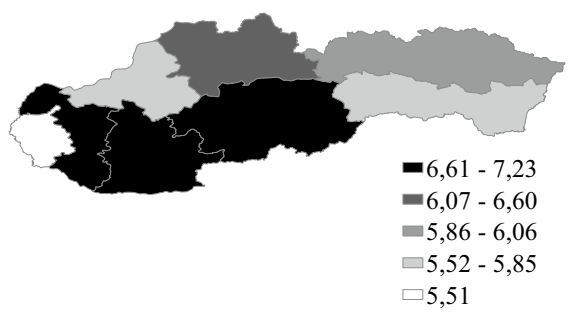

b

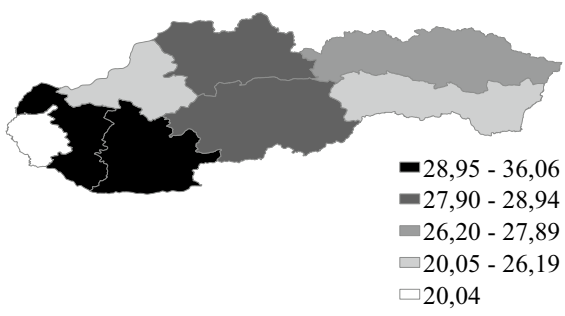

[

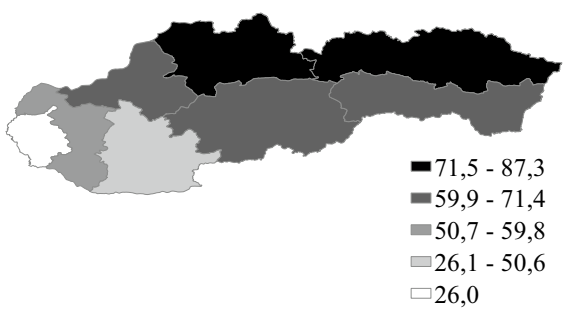

Fig. 6 Contribution of Slovak regions to a national innovation system synergy, b national knowledge exploration, and $\mathbf{c}$ organisational control. d Slovak counties' level of knowledge exploitation (all in millibits). Source: Authors' own elaboration

Therefore, knowledge flows are more likely to occur in the network between partners who share similar socio-cultural background and are part of the same local innovation system.

Secondly, synergy was continuously decreasing in case of both Central European countries in the analysed time period from 1998 to 2014 (however, in Hungary only until 2010, after that, synergy increased to the value of period 2002-2006). On the one hand, it is due to the nature of the fastest-growing creative industries (namely,

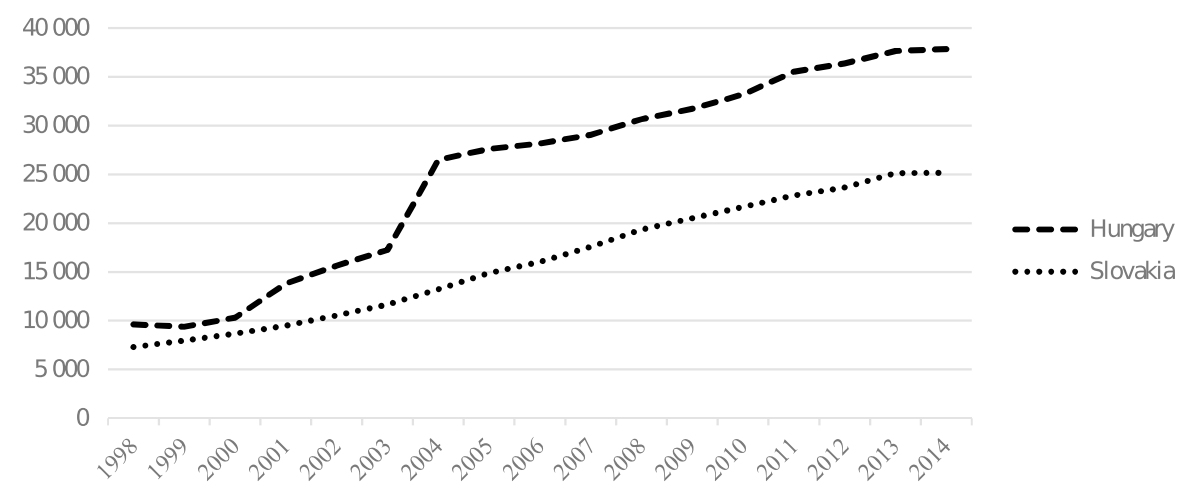

Fig. 7 Number of firms in creative industries with symbolic knowledge base in Slovakia and Hungary 1998-2014. Source: Authors' own elaboration 
NACE Rev 1. 7440 advertising in Slovakia, 7420 architectural and engineering activities and related technical consultancy, and 7487 other business activities, n.e.c. in Hungary) and on the other hand to globalisation. These creative industries produce local, and the source of innovation primarily is local; however, the output itself is often intangible. Due to the deterritorialised nature of end-products, the products and services can be easily transferred globally by different ICT solutions or reach the global market integrated into other industrial products (e.g. automotive industry). Furthermore, firms in creative industries are generally significantly smaller than firms in other parts of the economy, making them more flexible to compete in the international market.

\section{Conclusion}

After the fall of the communist regime and the transformation from a centrally planned economy to a decentralised market economy, creative industries started to grow in Central Europe, and their number is increasing year by year. Creative industries are considered one of the new engines of economic growth, have high innovation potential, employ highly qualified and skilled workforce, and build on local capacities. Symbolic nature of knowledge base in creative industries crucially influences their adaptability to innovate and contribute to regions to develop new growth paths.

In Central Europe, there was no empirical evidence before for the contribution of creative industries related to the emerge of synergies in innovation systems. Based on the concept of configuration of systems, we can measure synergy in innovation systems divided then into local, regional, and national parts. We distinguished three dimensions (geography, technology, and organisation) that operate in innovation systems and measured their interactions using entropy statistics.

Results show that in the case of creative industries with symbolic knowledge base, the largest part of the synergy is generated within the local level. In line with our theory-led expectation, in case of creative industries in Central Europe, geographical co-location is extremely important, and industries can contribute to the development of post-socialist knowledge-based economies. However, the degree of synergy in the creative industries is also affected by globalisation. Even though knowledge is created locally, knowledge spreads globally. Knowledge incorporated in end-products are often intangible in creative industries, can be transferred easily through info-communication tools, or reach the global market incorporated in other industrial products.

Our results have implications for the regional innovation policy. The research firstly confirms the importance of creative industries in connection with the establishment of regional advantages. Secondly, there is no doubt that despite local embeddedness, symbolic knowledge-based industries are also exposed to globalisation. Therefore, regional innovation policy must be adapted to the local context, and its tools must be tailored to specific local conditions. A one-size-fits-all approach will not work as symbolic knowledge-based creative industries require a local approach to potential partners who share a similar socio-economic background; thus, the local level of government has become more relevant. The local government 
should focus on implementation support policy programmes aiming at creation inter-organisational networks (mainly informal) since knowledge about possible partners for cooperation and knowledge exchange (know-who knowledge) is of considerable importance for symbolic knowledge-based industries.

Author Contribution Conceptualization: Zsófia Vas, Izabella Szakálné Kanó, Slávka Klasová. Methodology: Izabella Szakálné Kanó. Formal analysis and investigation: Izabella Szakálné Kanó. Writing original draft preparation: Slávka Klasová, Zsófia Vas, Izabella Szakálné Kanó. Writing — review and editing: Zsófia Vas, Izabella Szakálné Kanó. Funding acquisition: Izabella Szakálné Kanó, Zsófia Vas. Data resources: Izabella Szakálné Kanó, Slávka Klasová.

Funding Open access funding provided by University of Szeged. This research was supported by the project nr. EFOP-3.6.2-16-2017-00007, titled "Aspects on the development of intelligent, sustainable and inclusive society: social, technological, innovation networks in employment and digital economy". The project has been supported by the European Union, co-financed by the European Social Fund and the budget of Hungary.

Availability of Data and Material A unique database has been used to measure the configuration of innovation systems in Central Europe based on creative industries with a symbolic knowledge base. The firmlevel database (legal entities using double-entry bookkeeping) in Slovakia from the Statistical Register of Organization was provided by Statistical Office of Slovak Republic and in Hungary was provided by the Hungarian Central Statistical Office. All available data were gathered between the years 1998 and 2014.

Code Availability Configurational information (synergy) is calculated for both countries and each administration level (national, regional and local) by using STATA according to the description provided through the website: http://www.leydesdorff.net/software/th4/th4.prg.

\section{Declarations}

Ethics Approval Part of the study is an improved version of Slávka Klasová's and Miriam Sebová's previous conference paper, "The Possibilities of Regional Symbolic Knowledge Base for Resilience of the Regions." We did not use in our study parts of the previous one written by Miriam Sebová.

Consent to Participate All authors agreed with the content and all gave explicit consent to submit the current version of the manuscript.

Consent for Publication All the authors hereby declare that they give their consent for the article to be published in the Journal of the Knowledge Economy.

Conflict of Interest The authors declare no competing interests.

Open Access This article is licensed under a Creative Commons Attribution 4.0 International License, which permits use, sharing, adaptation, distribution and reproduction in any medium or format, as long as you give appropriate credit to the original author(s) and the source, provide a link to the Creative Commons licence, and indicate if changes were made. The images or other third party material in this article are included in the article's Creative Commons licence, unless indicated otherwise in a credit line to the material. If material is not included in the article's Creative Commons licence and your intended use is not permitted by statutory regulation or exceeds the permitted use, you will need to obtain permission directly from the copyright holder. To view a copy of this licence, visit http://creativecommons.org/ licenses/by/4.0/. 


\section{References}

Abramson, N. (1963). Information theory and coding. McGraw-Hill.

Asheim, B. T., \& Coenen, L. (2006). contextualising regional innovation systems in a globalising learning economy: On knowledge bases and institutional frameworks. Journal of Technology Transfer, 1 , 163-173. https://doi.org/10.1007/s10961-005-5028-0

Asheim, B. T., Coenen, L., \& Vang, J. (2007). Face-to-face, buzz, and knowledge bases: Sociospatial implications for learning, innovation, and innovation policy. Environment and Planning C: Government and Policy, 5, 655-670. https://doi.org/10.1068/c0648

Asheim, B. T., \& Gertler, M. S. (2005). The geography of innovation: Regional innovation systems. In J. Fagerberg, D. C. Mowery, \& R. R. Nelson (Eds.), The Oxford Handbook of Innovation (pp. 291317). Oxford University Press. https://doi.org/10.1093/oxfordhb/9780199286805.003.0011

Asheim, B., Boschma, R., \& Cooke, P. (2011). Constructing regional advantage: Platform policies based on related variety and differentiated knowledge bases. Regional Studies, 7, 893-904. https://doi.org/ 10.1080/00343404.2010.543126

Aslesen, E., \& Freel, P. (2012). Industrial knowledge bases as drivers open innovation? Industry and Innovation, 7, 563-584. https://doi.org/10.1080/13662716.2012.726807

Bialic-Davendra, M., Bednář, P., Danko, L., \& Matošková, J. (2016). Creative clusters in Visegrad countries: Factors conditioning cluster establishment and development. Bulletin of Geography. Socioeconomic Series, 32, 33-47.

Boix, R., Capone, F., De Propris, L., Lazzeretti, L., \& Sanchez, D. (2016). Comparing creative industries in Europe. European Urban and Regional Studies, 4, 935-940. https://doi.org/10.1080/00343404. 2019.1625484

Boix-Domènech, R., \& Rausell-Köster, P. (2018). The economic impact of the creative industry in the European Union. In: Santamarina-Campos, V., Segarra-Oña, M. eds., Drones and the Creative Industry. Cham: Springer, pp 19-36. https://doi.org/10.1007/978-3-319-95261-1

Boschma, R. A., \& Iammarino, S. (2009). Related variety, trade linkages and regional growth in Italy. Economic Geography, 85, 289-311. https://doi.org/10.1111/j.1944-8287.2009.01034.x

Blau, P. M., \& Schoenherr, R. (1971). The structure of organisations. Basic Books.

Braczyk, H. J., Cooke, P., \& Heidenreich, M. (2004). Regional innovation systems. The role of governance in a globalised world (2nd ed.). Routledge.

Chaminade, C. (2011). Are knowledge bases enough? A comparative study of the geography of knowledge sources in China (Great Beijing) and India(Pune). European Planning Studies, 19(7), 13571373. https://doi.org/10.1080/09654313.2011.573171

Chapain, C., Cooke, P., De Propris, D., MacNeill, S., \& Mateos-Garcia, J. (2010). Creative clusters and innovation. NESTA Research report.

Cooke, P., \& Lazzeretti, L. (eds) (2008). Creative cities, cultural clusters and local economic development. Cheltenman - Northampton: Edwar Elgar Publishing. https://doi.org/10.4337/9781847209948

De-Miguel-Molina, B., Hervas-Oliver, J. L., Boix, R., \& De-Miguel-Molina, M. (2012). The importance of creative industry agglomerations in explaining the wealth of European Regions. European Planning Studies, 8, 1263-1280. https://doi.org/10.1080/09654313.2012.680579

Dosi G., Orsenigo, L., \& Labini, M. S. (2005). Technology and the economy. In: Smelser, N. J., Swedberg, R. eds., The handbook of economic sociology. Princeton: Princeton University Press, Russell Sage Foundation.

EY. (2014). Creating growth. Measuring cultural and creative markets in the EU. London: Ernst \& Young.

Felton, E., Gibson, M. N., Flew, T., Graham, P., \& Daniel, A. (2010). Resilient creative economies? Creative Industries on the Urban Fringe. Continuum, 4, 619-630. https://doi.org/10.1080/10304312. 2010.485675

Fidrmuc, J., Fidrmuc, J., \& Horvath, J. (2002). Visegrad economies: Growth experience and prospects. Report prepared for the GDN global research project: Determinants of economic growth. Centre for European Integration Studies.

Flew, T. (2012). The creative industries, culture and policy. Sage Publication. https://doi.org/10.4135/ 9781446288412

Florida, R. (2002). Rise of the creative class. Basic Books.

Florida, R. (2005), Cities and creative class. New York - London: Routledge. https://doi.org/10.4324/ 9780203997673 
Foray, D., Goddard, J., Beldarrain, X. G., Landabaso, M., McCann, P., Morgan, K., \& Ortega-Argilés, R. (2012). Guide to research and innovation strategies for smart specialisations (RIS 3). European Commission, DG Regional Policy.

Fritsch, M. (2004). Cooperation and the efficiency of regional R\&D activities. Cambridge Journal of Economics, 28, 829-846. https://doi.org/10.1093/cje/beh039

Gülcan, Y., Akgüngör, S., \& Kuştepeli, Y. (2011). Knowledge generation and innovativeness in Turkish textile industry: Comparison of Istanbul and Denizli. European Planning Studies, 19(7), 12291243. https://doi.org/10.1080/09654313.2011.573134

Hartley, J. (Ed.). (2005). Creative Industries. Blackwell Publishing Ltd.

Hekkert, M. P., Suurs, R. A., Negro, S. O., Kuhlmann, S., \& Smits, R. E. (2007). Functions of innovation systems: A new approach for analysing technological change. Technological forecasting and social change, 4, 413-432. https://doi.org/10.1016/j.techfore.2006.03.002

Jakulin, A., \& Bratko, I. (2004). Quantifying and visualising attribute interactions: An approach based on entropy. Available at: http://arxiv.org/abs/cs.AI/0308002

Johnston, R. J., Gregory, D., Pratt, G., \& Watts, M. (2000). The dictionary of human geography. Blackwell.

Kemeny, T., Nathan, M., \& O’Brien, D. (2020). Creative differences? Measuring creative economy employment in the United States and the UK. Regional Studies, 3, 377-387. https://doi.org/10.1080/ 00343404.2019 .1625484

Kornai, J. (2006). The great transformation of Central Eastern Europe. Success and Disappointment. Economics of Transition, 2, 207-244. https://doi.org/10.1111/j.1468-0351.2006.00252.x

Lazzeretti, L. (ed) (2013). Creative industries and innovation in Europe. London - New York: Routledge. https://doi.org/10.4324/9780203112571

Lengyel, B., \& Leydesdorff, L. (2011). Regional innovation systems in Hungary: The failing synergy at the national level. Regional Studies, 5, 677-693. https://doi.org/10.1080/00343401003614274

Lengyel, B., \& Leydesdorff, L. (2015). The effects of FDI on innovation systems in Hungarian regions: Where is the synergy generated? Regional Statistics, 5(1), 3-24. https://doi.org/10.15196/RS05101

Leydesdorff, L., Dolfsma, W., \& Van Der Panne, G. (2006). Measuring the knowledge base of an economy in terms of triple helix relations among technology, organization, and territory. Research Policy, 35, 181-199. https://doi.org/10.1016/j.respol.2005.09.001

Leydesdorff, L., \& Fritsch, M. (2006). Measuring the knowledge base of regional innovation systems in Germany in terms of a triple helix dynamics. Research Policy, 35, 1538-1553. https://doi.org/10. 1016/j.respol.2006.09.027

Leydesdorff, L. (2003). The mutual information of university-industry-government relations: An indicator of the triple helix dynamics. Scientometrics, 2, 445-467. https://doi.org/10.1023/A: 1026253130577

Liu, J., Chaminade, C., \& Asheim, B. (2013). The geography and structure of global innovation networks: A knowledge base perspective. European Planning Studies, 21(9), 1456-1473. https://doi. org/10.1080/09654313.2012.755842

Lundvall, B. -A. (Ed.). (1992). National system of innovation. Towards a Theory of Innovation and Interactive Learning. Pinter Publisher.

Malecki, E. J., \& Hospers, G. -J. (2007). Knowledge and the competitiveness of places. In R. Rutten \& F. Boekema (Eds.), The Learning Region: Foundations, State of Art, Future (pp. 143-159). Cheltenham Edward Elgar.

Martin, R. (2012). Measuring knowledge bases in Swedish Regions. European Planning Studies, 9 , 1-14. https://doi.org/10.1080/09654313.2012.708022

Martin, R., \& Moodysson, J. (2011). Innovation in symbolic industries: the geography and organisation of knowledge sourcing. European Planning Studies, 19, 1183-1203. https://doi.org/10.1080/ 09654313.2011 .573131

Martin, R., \& Moodysson, J. (2013). Comparing knowledge bases: On the geography and organization of knowledge sourcing in the regional innovation system of Scania. Sweden. European Urban and Regional Studies, 20(2), 170-187. https://doi.org/10.1177/0969776411427326

Martin, R., \& Sunley, P. (2015). On the notion of regional economic resilience: conceptualisation and explanation. Journal of Economic Geography, 1, 1-42. https://doi.org/10.1093/jeg/lbu015

McGill, W. J. (1954). Multivariate information transmission. Psychometrika, 2, 97-116. https://doi.org/ 10.1007/BF02289159 
Mikić, H., Branko, R., \& Miljan, S. (2020). Creative industries in Serbia: Methodological approaches and economic contribution. Ekonomika Preduzeća, 3-4, 201-214. https://doi.org/10.5937/ EKOPRE2004201M

Nelson, R. R. (ed) (1993): National innovation system. A comparative analysis. Oxford - New York: Oxford University Press.

Power, D., \& Scott, A. J. (2004). Cultural industries and the production of culture. New-York - London: Routledge. https://doi.org/10.4324/9780203392263

Plum, O., \& Hassink, R. (2011). Comparing knowledge networking in different knowledge bases in Germany. Papers in Regional Science, 90(2), 355-371. https://doi.org/10.1111/j.1435-5957.2011. 00362.x

Plum, O., \& Hassink, R. (2014). Knowledge bases, innovativeness and competitiveness in creative industries: The case of Hamburg's video game developers. Regional Studies, Regional Science, 1, 248268. https://doi.org/10.1080/21681376.2014.967803

Pratt, C. A. (2015). Resilience, locality and the cultural economy. City, Culture and Society, 6, 61-67. https://doi.org/10.1016/j.ccs.2014.11.001

Pugh, D. S., Hickson, D. J., \& Hinings, C. R. (1969). An empirical taxonomy of structures of work organisations. Administrative Science Quarterly, 1, 115-126. https://doi.org/10.2307/2391367

Shannon, C. E. (1948). A mathematical theory of communication. Bell System Technical Journal, 3, 379423. https://doi.org/10.1002/j.1538-7305.1948.tb01338.x

Simmie, J. (2014). Regional economic resilience: A Schumpeterian perspective. Raumforschung und Raumordnung, Spatial Research and Planning, 2, 103-116. https://doi.org/10.1007/s13147-014-0274-y

Stam, E., de Jong, J. P. J., \& Marlet, G. (2008). Creative industries in the Netherlands: Structure, development, innovativeness and effects on urban growth. Geografiska Annaler: Series B, Human Geography, 90, 119-132. https://doi.org/10.1111/j.1468-0467.2008.00282.x

Swyngedouw, E. (2000). Elite power, global forces, and the political economy of 'glocal' development. In G. L. Clark, M. P. Feldman, \& M. S. Gertler (Eds.), The Oxford Handbook of Economic Geography (pp. 541-558). Oxford University Press.

Theil, H. (1972). Statistical decomposition analysis: With applications in the social and administrative sciences. No. 04; HA33, T4, Amsterdam: North-Holland.

Ulanowicz, R. E. (1986). Growth and development: Ecosystems phenomenology. Springer-Verlag.

UNCTAD. (2008). Creative Economy Report, 2010. Geneva: United Nations Conference on Trade and Development.

UNCTAD. (2010). Creative Economy Report, 2010. Geneva: United Nations Conference on Trade and Development.

Publisher's Note Springer Nature remains neutral with regard to jurisdictional claims in published maps and institutional affiliations. 